\title{
Assessment of Quality Education in Private Secondary Schools of Khyber Pakhtunkhwa (Pakistan)
}

\author{
Atta Ur Rahman'and Niaz Muhammad Aajiz² \\ 'Sarhad University of Science and Information Technology, Peshawar \\ 2Islamia College University, Department of Education
}

\section{Abstract}

The current study evaluates the quality of education in private secondary schools of Khyber Pakhtunkhwa (Pakistan). It is descriptive in nature. The study population included principals, teachers and students of private secondary schools of Kohat. All the principals of 30 private secondary schools were selected as sample whereas random sampling technique was employed for selecting the study sample of teachers and students. Three different questionnaires were framed by using a five-point Likert scale. Data were interpreted by simple percentages. The results revealed that majority of teachers of private secondary schools are professionals, yet they were not content with their pay and service structure. It was concluded that the schools follow the curriculum prescribed by Education Boards. There were scientific labs, but there was also a lack of modern and contemporary books in libraries.

Key words: facilities; private schools; qualified teachers; secondary school level.

\section{Introduction}

Education is a systematic way of gathering information, gaining skills and developing ambitions of individuals, and then transferring them to the next generation by preparing or exploring the potential. Learning is a social tool by which one directs one's fate and plans one's expectations. Educated individuals are capable of working, thus making education more compelling to produce effective citizens, who in turn support the financial advancement of the nation. Henceforth, the role of education is vital to create the learning economy since educated and talented masses assume an essential part in the advancement/success of the nation. To achieve the goal of the educated and talented generation, vast investment in education is critical, as education would help the partners in changing their mentality to achieve the 
maximum rate of literacy. Private and public development sectors need to fulfil their social obligations of imparting quality education (Pakistan Education Statistics, 2013-2014).

Educational quality guarantees social improvement of the general public. However, a quality result is emphatically viewed on the grounds of quality of input, which incorporates brilliance of educators, excellence of educational programs, excellence of the facilities, sufficient use of training and nature of administration that guarantee smooth usage of administrative laws for quality yield. Developed nations allot adequate sums of money for the arrangement of instruction, while investment in education in developing nations is insufficient. In Pakistan, the funds allocation for education is not sufficient (Government of Pakistan, 2009). Henceforth, the scarcity of assets and insufficient facilities led to a high rate of school dropout (Government of Pakistan, 2011, 2012).

Because of inadequate budgeting plan for education, it would be unimaginable for public sector to cater for the educational needs of quickly expanding population of Pakistan, which is $2.7 \%$. So, it is normal to expect that private sector may take part in educational endeavors (Government of Pakistan, 2010, 2011). The private sector has been putting forth the support to share the weight of its partner public sector since 1947. Still, the strategy of nationalization (1972) caused serious frustration among the private sector since it limited their provision and its final effect was reflected in learners' enrolment in government- and non-government-financed education sector - the ratio was 70:30 (Isani \& Virk, 2003).

Although nationalization policy was turned around in 1979 and the nationalized schools were given to their previous owners, the laissez-faire policies of government toward private schools have polarized the education. The government of Pakistan gives no budgetary support to non-public schools and they survive absolutely in response to market forces. Regardless of the laissez-faire arrangement of the administration, the private sector managed to stretch out its education services even in the regions and within a short time, to enhance literacy rate soon after 1979. After that, the government perceived that the quick development of private education sector in Pakistan was probable because of the poor education of government schools (Wotson, 2005).

\section{Objectives of the Study}

The current study was performed with the following objectives:

1. To evaluate the quality of education in terms of management quality, curriculum quality, and quality of facilities, quality of the teaching methods and quality of extracurricular activities in private secondary schools.

2. To analyze the teachers' academic and professional qualifications and their pay in private secondary schools.

3. To recommend suitable measures for improving educational quality in private secondary schools. 


\section{Literature Review}

It is easier to clarify the term quality than to define it. When we compare things and choose a better one, it is usually of better quality. Quality can be seen as confirmation to a standard (NAAC, 1995). The term quality is the degree of excellence which a product or service provides. It is difficult to define. Provision of quality encompasses access to education. It is often used as a synonym for excellence. It influences what students learn, how well they learn and what benefits they draw from their education. Students' desired learning outcomes and acquisition of values and skills that help them play a positive role in their societies are known as quality (Baaji, 2006). In a comparative setting, private schools are considered as commercialized education, which is mostly imparted for business purposes, while public sector is for the most part viewed as customary supplier of education on the grounds that there is an incredible concern about the public sector because they impart quality education to the youngsters (I-SAPS, 2010). As indicated by Iqbal (2006), private schools give more instructional material and their instructors utilize activity-based methods of teaching and organize more extracurricular activities when compared with public schools.

The nature of learning materials accessible in an educational institution has a positive correlation with the coaching and learning tasks, which results in the achievement of the set objectives (Ayeni \& Adelabu, 2012). School material resources and instructional materials, such as course books and reference books, are believed to be fundamental contributors to students' academic accomplishment in school. The accessibility of the reading materials and reference books in school bookshops and libraries does not ensure the quality of school, unless they are circulated to learners during a school year (Earthman, 2002).

Instructional materials and related material sources of knowledge that are connected with education are related to better student accomplishment. The accessibility of course readings and other instructional materials has a reliably beneficial outcome for student accomplishment in developing nations. Moreover, it has become very important in the last decades since it was proved that learning materials are essential and plausible assurance of academic accomplishment (Semaw, 2009).

The essential explanation behind the low quality of education was the preparation, and also the general state of mind toward the teachers. In the past, anyone could have been employed as an educator, both at the lower and higher level, for there was no checking system to assess the candidate's ability and readiness. With the specific goal to amend these troublesome circumstances, criteria that educators at each level must meet have been set. Therefore, the teachers at any level of education ought to have the important training, which is subsequently the strong foundation for an instructor. The most vital factor influencing the teaching and learning process is the competency and quality of the individual teacher in the classroom. 
Girma (2010) claims that there is a clear proof that a teacher's competency and effectiveness are the most compelling determinants of student accomplishment. How educators are prepared for teaching is a basic determinant of education quality. He verifies that the quality of the teacher depends on understanding of and the nature of training they have received. It likewise relies upon the teacher's behavior and the relationship the teacher has with the students. The important characteristics of the competent teacher are: qualifications, teacher training, experience, aptitude and teaching practices, comprehension of technology and the capacity to work cooperatively with different educators, individuals and guardians. Lue (2005) believes that the curriculum of instruction quality refers to the expected and implemented educational modules of schools, national objectives for education and result statements that translate those objectives into measureable goals. The curriculum ought to stress deep and vital areas of learning, contextualized issues of study and critical thinking that insist on abilities improvement, as well as obtaining information. UNICEF (2000) clarifies that interests of community may likewise affect and add to the quality of instructive contents. In all nations, in any case, the contents of quality ought to integrate significant areas. These incorporate proficiency, numeracy, life skills and peace instruction, and additionally science and social studies.

Bedi and Garg (2000), using data from Indonesia, confirmed that students who had been admitted in private-based schools at the post-elementary school level achieved superior results in comparison to those who had been educated in statefinanced institutions. They analyzed the differences in results achieved by students from state and private schools. In this examination, it was revealed that private school graduates are getting higher financial rewards later in their lives than their peers from state schools.

Joshua (2012) states that in developed countries, parents/legal guardians visit schools to examine accessibility and the state of facilities before deciding to enroll their kids in a particular school. Indeed, even in developing nations, the Ministry of Education trusts that school facilities have influence on the access and quality. The school facilities are tools to attract students, especially girls, when all is said and done. The facilities seem to have a deciding role and can fascinate students. The school with the given facilities additionally guarantees that students learn in a standard environment. The basic standard facilities each school ought to have are:

(i) Separate latrine facilities for young boys and young girls.

(ii) Adequate water supply point for washing and drinking.

(iii) Counseling services for individual education-related issues.

(iv) An adequate library and laboratory suitable for the level of education and an adequate playground.

He further adds that the nature of the school structures, furniture, agreeable classrooms and sufficient arrangement of instructional resources encourage educators' teaching performance and students' learning results. Street (2008) states 
that regardless of whether school laboratory influences student academic results or not, its importance cannot be neglected. He says that the school laboratory has affected positively student academic achievement. The number of students in research facility classes and time spent in lab classrooms were associated with achievement. Additionally, it has been demonstrated that school laboratory has a positive outcome related to student academic achievement. Getahun (2002) states that libraries assume the linking role amongst subjects learnt by the students and help students apply science and arithmetic ideas to alternate disciplines. Libraries are places where educational science programs can be developed, where electronic databases contain the most recent data, where guest speakers are invited and where students can present their projects. The World Bank discussion report was based on 18 investigations of the impact of library size and its activities on student accomplishment. In 15 cases they have demonstrated a positive effect. This recommendation demonstrates that school libraries have a critical role in students' accomplishments. Students who are working in well-equipped libraries achieve good results, while students working in poor libraries achieve the opposite results.

Moreover, Farida and Madiha (2000) additionally deduced in their work that in private sector the heads were more stressed with respect to extracurricular activities since they think of them as a necessary element of instruction.

The ASER Pakistan (2010) overview also shows that in state schools there were more classrooms, better drinking water, toilets and boundary walls for security. As per the Learning and Education Achievements in Punjab Schools (LEAPS), the students' learning standards in private establishments are superior to public sector although higher pay and better resources are provided to latter. Nonetheless, the Government of Pakistan indicates genuine concerns and prescribes screening of the working of private educational institutes with respect to instructors' capabilities, educational programs, physical facilities and structures, since it is risky to depend on private organizations. The trend of practical and scientific experiments in private secondary schools is weakening and this will result in dangers to the education. So, there is a need to reinforce the public-private partnership bond since one of the principal challenges of private sector is an inclination to augment benefit. There is an additional concern that in the private sector the income and rights of the workers are reduced. In the private sector, there are fewer opportunities for employees to get advantages and benefits which require critical changes on the grounds that the instructors' loyalty and sincerity may then become doubtful (Government of Pakistan, 2008). The other rationalization for regulation is focused on private school educators' qualifications and professional capabilities. Most private schools hire low-qualified and less professionally prepared instructors, and a few researchers examined the quality issues. Indeed, even some private schools in distant regions have employed local female instructors, who had never received proper education outside their towns (Andrabi et al., 2002). 
Mustaqeem (2008) presumed that private school teachers have higher determination than the instructors in state schools. Besides, Liaqat (2009) found that the schooling quality of private schools is better when contrasted with state-funded schools and the studies in private secondary schools reliably demonstrated better results when contrasted with public schools.

\section{Research Methodology}

The study was descriptive in nature. The population of the study consisted of principals, teachers and students in private secondary schools in Kohat. All the principals $(\mathrm{N}=30)$ of private secondary schools were selected as sample whereas random sampling technique was employed for selecting 300 tenth-grade students and 150 teachers, by taking 10 students and 5 teachers per school. The basic information was gathered from principals, teachers and students of private secondary schools in Kohat. Survey procedure was adapted to elicit opinions by using three different questionnaires for principals, students and teachers. Cronbach's alpha was employed for internal consistency of items in the questionnaires. The alpha values for each question were higher than 0.89 . The statements in the questionnaires were formed by using a 5 -point Likert scale. Percentages were calculated to examine the data. The results were obtained on the basis of calculations.

\section{Data Analysis and Results}

This section presents the investigation and understanding of the information collected through questionnaires with the respondents, and contains data about private secondary schools (principals, teachers and students in Kohat).

Table 1

Teachers' academic qualifications

\begin{tabular}{ccc}
\hline \multicolumn{3}{c}{ Academic qualifications } \\
\hline Qualification & Number & Percentage \\
\hline Ph.D. & 0 & 0 \\
M.Phil. & 3 & 2 \\
M.A./M.Sc. & 84 & 56 \\
B.A./B.Sc. & 54 & 36 \\
Other & 9 & 6 \\
Total & 150 & 100 \\
\hline
\end{tabular}

Table 1 demonstrates that in private secondary schools in Kohat more than a half of employees hold master's degrees, while only $36 \%$ are bachelor degree holders.

Table 2 shows that almost one fourth of the educators are uneducated and around $10 \%$ are not professionally trained for secondary classes. It shows that $32 \%$ of the teachers hold professional master's degree, while 33\% hold bachelor's degrees. 
Table 2

Teachers' professional qualifications

\begin{tabular}{ccc}
\hline \multicolumn{3}{c}{ Professional qualifications } \\
\hline Qualification & Number & Percentage \\
M.Ed. & 48 & 32 \\
B.Ed. & 50 & 33 \\
C.T. & 9 & 6 \\
PTC & 6 & 4 \\
Uneducated & 37 & 25 \\
Total & 150 & 100
\end{tabular}

Note: C.T. stands for certificate in teaching and PTC stands for Primary Teaching Certificate.

Table 3

Principals' opinions about teachers' salaries and incentives

\begin{tabular}{lcccccc}
\hline Teachers of your school & $\mathrm{SA}$ & $\mathrm{A}$ & $\mathrm{UN}$ & $\mathrm{DA}$ & $\mathrm{SDA}$ & Total \\
\hline Have job security & 6 & 4 & 3 & 5 & 12 & 30 \\
Are satisfied with salaries & $(20 \%)$ & $(13 \%)$ & $(10 \%)$ & $(16 \%)$ & $(40 \%)$ & 30 \\
Are encouraged by incentives & 3 & 7 & 7 & 10 & 3 & 30 \\
& $(10 \%)$ & $(23 \%)$ & $(23 \%)$ & $(33 \%)$ & $(10 \%)$ & \\
& $(13 \%)$ & 4 & 6 & 7 & 9 & 30 \\
\hline
\end{tabular}

( $\mathrm{SA}=$ strongly agree; $\mathrm{A}=$ agree; $\mathrm{UN}=$ undecided; $\mathrm{DA}=$ disagree and $\mathrm{SDA}=$ strongly disagree)

Table 4

Teachers' opinions about salaries and incentives

\begin{tabular}{lcccccc}
\hline Teachers of private secondary schools & SA & A & UN & DA & SDA & Total \\
\hline Are satisfied with salaries & 6 & 14 & 10 & 36 & 84 & 150 \\
& $(4 \%)$ & $(9 \%)$ & $(6 \%)$ & $(24 \%)$ & $(56 \%)$ & \\
Are encouraged by incentives & 4 & 18 & 20 & 58 & 50 & 150 \\
Have service structure & $(2 \%)$ & $(12 \%)$ & $(12 \%)$ & $(38 \%)$ & $(33 \%)$ & \\
& 7 & 11 & 20 & 43 & 69 & 150 \\
\hline
\end{tabular}

( $\mathrm{SA}=$ strongly agree; $\mathrm{A}=$ agree; $\mathrm{UN}=$ undecided; $\mathrm{DA}=$ disagree and $\mathrm{SDA}=$ strongly disagree)

Tables 3 and 4 indicate that the teachers were unhappy with their compensation. There was no incentive, service structure and sensible pay for educators in private secondary schools.

Table 5

Teachers' opinions about the curriculum

\begin{tabular}{lcccccc}
\hline The curriculum in private secondary schools & SA & A & UN & DA & SDA & Total \\
\hline Meets the needs of society & 62 & 58 & 10 & 18 & 2 & 150 \\
& $(41 \%)$ & $(38 \%)$ & $(6 \%)$ & $(12 \%)$ & $(1 \%)$ & \\
Develops critical thinking & 85 & 35 & 8 & 10 & 12 & 150 \\
& $(56 \%)$ & $(23 \%)$ & $(5 \%)$ & $(6 \%)$ & $(8 \%)$ & \\
Is helpful in achieving objectives & 40 & 72 & 7 & 11 & 20 & 150 \\
& $(26 \%)$ & $(48 \%)$ & $(4 \%)$ & $(7 \%)$ & $(12 \%)$ & \\
\hline
\end{tabular}

( $\mathrm{SA}=$ strongly agree; $\mathrm{A}=$ agree; $\mathrm{UN}=$ undecided; $\mathrm{DA}=$ disagree and $\mathrm{SDA}=$ strongly disagree) 
Table 5 demonstrates that educational modules of private schools are dynamic and uniform at secondary level, which provides material to address the needs of society. These schools follow the educational modules of Khyber Pakhtunkhwa Textbook Board Peshawar as endorsed by Boards of Intermediate and Secondary Education.

Table 6

Students' opinions about facilities

\begin{tabular}{|c|c|c|c|c|c|c|}
\hline Your school has & SA & A & UN & DA & SDA & Total \\
\hline Updated sufficient books in library & $\begin{array}{c}46 \\
(15 \%)\end{array}$ & $\begin{array}{c}83 \\
(27 \%)\end{array}$ & $\begin{array}{c}32 \\
(11 \%)\end{array}$ & $\begin{array}{c}65 \\
(21 \%)\end{array}$ & $\begin{array}{c}74 \\
(22 \%)\end{array}$ & 300 \\
\hline Well-equipped scientific laboratory & $\begin{array}{c}81 \\
(27 \%)\end{array}$ & $\begin{array}{c}107 \\
(35 \%)\end{array}$ & $\begin{array}{c}39 \\
(13 \%)\end{array}$ & $\begin{array}{c}44 \\
(14 \%)\end{array}$ & $\begin{array}{c}29 \\
(10 \%)\end{array}$ & 300 \\
\hline Well-furnished classrooms & $\begin{array}{c}84 \\
(28 \%)\end{array}$ & $\begin{array}{c}138 \\
(46 \%)\end{array}$ & $\begin{array}{c}35 \\
(12 \%)\end{array}$ & $\begin{array}{c}21 \\
(7 \%)\end{array}$ & $\begin{array}{c}22 \\
(7 \%)\end{array}$ & 300 \\
\hline Adequate furniture & $\begin{array}{c}111 \\
(37 \%)\end{array}$ & $\begin{array}{c}122 \\
(15 \%)\end{array}$ & $\begin{array}{c}28 \\
(9 \%)\end{array}$ & $\begin{array}{c}22 \\
(7 \%)\end{array}$ & $\begin{array}{c}18 \\
(6 \%)\end{array}$ & 300 \\
\hline Playground & $\begin{array}{c}88 \\
(29 \%)\end{array}$ & $\begin{array}{c}108 \\
(36 \%)\end{array}$ & $\begin{array}{c}37 \\
(12 \%)\end{array}$ & $\begin{array}{c}38 \\
(13 \%)\end{array}$ & $\begin{array}{c}29 \\
(10 \%)\end{array}$ & 300 \\
\hline Water and sanitary facilities & $\begin{array}{c}92 \\
(31 \%)\end{array}$ & $\begin{array}{c}96 \\
(32 \%)\end{array}$ & $\begin{array}{c}24 \\
(8 \%)\end{array}$ & $\begin{array}{c}50 \\
(17 \%)\end{array}$ & $\begin{array}{c}38 \\
(13 \%)\end{array}$ & 300 \\
\hline
\end{tabular}

( $\mathrm{SA}=$ strongly agree; $\mathrm{A}=$ agree; $\mathrm{UN}=$ undecided; $\mathrm{DA}=$ disagree and $\mathrm{SDA}=$ strongly disagree)

Table 6 demonstrates that in private secondary schools there was an adequate number of toilets, drinking water, furniture, classrooms and playgrounds; yet, there were no updated books in libraries in these schools.

Table 7

Students' opinions about teaching methodologies

\begin{tabular}{|c|c|c|c|c|c|c|}
\hline In your school & SA & A & UN & DA & SDA & Total \\
\hline Teachers provide democratic environment & $\begin{array}{c}105 \\
(35 \%)\end{array}$ & $\begin{array}{c}113 \\
(37 \%)\end{array}$ & $\begin{array}{c}51 \\
(17 \%)\end{array}$ & $\begin{array}{c}17 \\
(5 \%)\end{array}$ & $\begin{array}{c}14 \\
(5 \%)\end{array}$ & 300 \\
\hline Teachers are qualified and well-prepared & $\begin{array}{c}63 \\
(21 \%)\end{array}$ & $\begin{array}{c}176 \\
(58 \%)\end{array}$ & $\begin{array}{c}19 \\
(6 \%)\end{array}$ & $\begin{array}{c}20 \\
(7 \%)\end{array}$ & $\begin{array}{c}12 \\
(4 \%)\end{array}$ & 300 \\
\hline Teachers use AV aids & $\begin{array}{c}69 \\
(23 \%)\end{array}$ & $\begin{array}{c}167 \\
(55 \%)\end{array}$ & $\begin{array}{c}43 \\
(14 \%)\end{array}$ & $\begin{array}{c}13 \\
(4 \%)\end{array}$ & $\begin{array}{c}8 \\
(2 \%)\end{array}$ & 300 \\
\hline Homework is regularly given and checked & $\begin{array}{c}82 \\
(27 \%)\end{array}$ & $\begin{array}{c}136 \\
(45 \%)\end{array}$ & $\begin{array}{c}54 \\
(18 \%)\end{array}$ & $\begin{array}{c}18 \\
(6 \%)\end{array}$ & $\begin{array}{c}10 \\
(3 \%)\end{array}$ & 300 \\
\hline Teachers use questioning techniques & $\begin{array}{c}156 \\
(52 \%)\end{array}$ & $\begin{array}{c}80 \\
(26 \%)\end{array}$ & $\begin{array}{c}38 \\
(12 \%)\end{array}$ & $\begin{array}{c}15 \\
(5 \%)\end{array}$ & $\begin{array}{c}11 \\
(3 \%)\end{array}$ & 300 \\
\hline Discussion method is employed & $\begin{array}{c}148 \\
(49 \%)\end{array}$ & $\begin{array}{c}82 \\
(27 \%)\end{array}$ & $\begin{array}{c}45 \\
(15 \%)\end{array}$ & $\begin{array}{c}13 \\
(4 \%)\end{array}$ & $\begin{array}{c}12 \\
(4 \%)\end{array}$ & 300 \\
\hline Teachers give feedback & $\begin{array}{c}89 \\
(29 \%)\end{array}$ & $\begin{array}{c}149 \\
(49 \%)\end{array}$ & $\begin{array}{c}33 \\
(11 \%)\end{array}$ & $\begin{array}{c}17 \\
(5 \%)\end{array}$ & $\begin{array}{c}12 \\
(4 \%)\end{array}$ & 300 \\
\hline
\end{tabular}

( $\mathrm{SA}=$ strongly agree; $\mathrm{A}=$ agree; $\mathrm{UN}=$ undecided; $\mathrm{DA}=$ disagree and $\mathrm{SDA}=$ strongly disagree) 
Table 7 shows the educators are qualified and they use modern teaching methods in private secondary schools. The teachers provide democratic environment to the students and take feedback regularly.

Table 8

Students' opinions about the standards in private schools

\begin{tabular}{lcccccc}
\hline In your school & SA & A & UN & DA & SDA & Total \\
\hline Merit is strictly observed & 67 & 170 & 42 & 15 & 06 & 300 \\
& $(22 \%)$ & $(56 \%)$ & $(14 \%)$ & $(5 \%)$ & $(2 \%)$ & \\
English is used as a medium of instruction & 52 & 176 & 52 & 06 & 14 & 300 \\
& $(17 \%)$ & $(58 \%)$ & $(17 \%)$ & $(2 \%)$ & $(4 \%)$ & \\
Classroom management is effective & 70 & 160 & 40 & 15 & 15 & 300 \\
Fair discipline is observed & $(23 \%)$ & $(53 \%)$ & $(13 \%)$ & $(5 \%)$ & $(5 \%)$ & \\
There is good teacher student proportion & 162 & 72 & 39 & 17 & 10 & 300 \\
& $(54 \%)$ & $(24 \%)$ & $(13 \%)$ & $(6 \%)$ & $(3 \%)$ & \\
& $(29 \%)$ & $(36 \%)$ & $(12 \%)$ & $(13 \%)$ & $(10 \%)$ & 300 \\
\hline
\end{tabular}

( $\mathrm{SA}=$ strongly agree; $\mathrm{A}=$ agree; $\mathrm{UN}=$ undecided; $\mathrm{DA}=$ disagree and $\mathrm{SDA}=$ strongly disagree)

Table 8 demonstrates that most of the private secondary schools use English as a medium of instruction and have a better student-teacher ratio. Classroom management and discipline is maintained effectively in these schools.

\section{Discussion}

The fundamental reason for the current study was to look into the viability of private sector participation in the implementation of quality instruction at secondary level in Kohat. Secondary school level holds focal position in the framework of education since it supplies essential workforce for the economy and is a basis for further education, too. The private sector tended to tackle the quantitative aspect and concentrated on the quality aspects at secondary school level.

Administration has the focal position in the organization since administration is accountable for running the whole school system. The present study demonstrated that one fourth of the secondary school teachers were not adequately educated and only $10 \%$ of the teachers were not professionally qualified for secondary classes, whereas the majority of teachers were academically qualified. Andrabi et al. (2002) also support the finding of the present investigation that the vast majority of private schools employ teachers who are not sufficiently professionally qualified. The findings of the present examination were additionally augmented by Memon (2007), who found that a greater part of private schools have employed low-qualified instructors who have less knowledge about psychology of the students and instructional strategies. These organizations disregard the B.Ed. and M.Ed. degree holders and like to designate the individuals who have a greater knowledge of English. Moreover, there is no appropriate job security, service structure and motivation for the teachers in private secondary schools. 
The instructors were not happy with their salaries. Accordingly, among them a feeling of deprivation is created and they perceive private schools as transitory habitation. Because of the feeling of uncertainty, they leave their occupations, which adversely affects the psychology of students. Memon (2007) supports the finding that private schools lack support mechanism for teachers. The educators in the private sector demonstrate a lack of interest due to improper service structure and job security.

There were satisfactory number of toilets, drinking water, furniture and playground in private secondary schools; however, these schools were lacking in modern library books. The students confirmed that private secondary schools organize extracurricular activities due to their large area and the students were urged to take part in different exercises, like school sports. Iqbal (2006) also supports the finding of the present study that private English schools keep class size constrained and arrange extracurricular activities in their large premises, unlike state schools in Urdu.

The curriculum is an arrangement of activities which are carefully devised and selected to accomplish the desirable targets. The students and the teachers may engage in fruitless activities of the curriculum if it is not well-defined. Contrary to the belief that the private schools offer foreign curricula, it was found in the present investigation that there was an agreement and consistency in the educational programs of both in private and state schools at the secondary level. On the other hand, the majority of private schools are registered with the Boards of Intermediate and Secondary Education of the province and they are bound to follow the curricula prescribed by these boards.

\section{Conclusions}

1. The teachers and principals have negative opinions about private secondary schools as these schools do not offer job security, rewards, service structure and appropriate payment for the teachers. Thus, the teachers were not happy with their salaries.

2. Students and the principals have positive attitudes regarding the teaching methods employed by the teachers. They claim that the teachers are experts in their respective subjects.

3. The students expressed affirmative statements regarding school facilities with respect to drinking water, an adequate number of toilets and furniture in private schools. Yet, in opposition to it, they indicated negative views due to not having satisfactory science research facilities and prepared libraries.

4. The current study obtained the opinions of students and teachers that extracurricular activities are organized in private schools and the students are spurred towards these activities. Additionally, the majority of instructors had very positive views with respect to students' interest in extra-curricular activities.

5. The majority of students had profoundly positive assessment in regards to the standard of private secondary schools with respect to the methods of teaching, classroom administration and student-teacher ratio. 


\section{Recommendations}

It is recommended that:

1.The teachers of private secondary schools must be guaranteed job security. The service structure of the teachers should be made.

2. The salaries of teachers in private secondary schools should be equalized with those of the public school teachers.

3. A sufficient number of updated books should be provided in the libraries of private secondary schools.

4.The uncertainty of the teachers in private secondary schools should be removed by motivation and financial incentives.

5.Professional courses should be arranged for untrained teachers to make them equal with the qualified ones.

\section{References}

Andrabi, T., Das, J., \& Khwaja, A. (2002). The rise of private schooling in Pakistan: Catering to the urban elite or educating the rural poor? Mimeo: Kennedy school of government, Harvard University.

Annual Status of Education Report (ASER) Pakistan 2010. (2010). Lahore, South Asian Forum for Education Development (SAFED).

Ayeni, A., \& Adelabou, M. A. (2012). Improving learning infrastructure and environment for sustainable quality assurance practice in secondary school: Ondo State, SouthWest, Nigeria. International Journal of Research Studies in Education, 1, 61-68. https://doi. org/10.5861/ijrse.2012.v1i2.49

Baaji, M. A. (2006). The concept of quality in education. Review of literature on the concept of quality in education. Sarhad University Journal of Management Sciences SUIT, Peshawar, 20,91-98.

Bedi, A. S., \& Garg, A. (2000). The Effectiveness of Private versus Public Schools: Case of Indonesia. Journal of Development Economics, 61, 463-469. https://doi.org/10.1016/S03043878(00)00065-1

Earthman, G. I. (2002). School facility conditions and student academic achievement. Los Angeles: University of California's institute for democracy, education and access. Retrieved from http://www.ucla-idea.org

Farida, B., \& Madiha, K. (2000). A comparative study of administrators' role in public and private secondary schools. (Unpublished Master's Thesis). Institute of Education and Research, University of Punjab, Lahore.

Getahun, W. (2002). School-based factors contributing to differences in students' achievement at high and low passing rate score secondary schools of Addis Ababa at national examination. Unpublished M.A. Thesis. Addis Ababa University. 
Girma, M. (2010). An assessment of the current status of quality of education in private higher education institution: The case of Makkele. (Unpublished Master's Thesis). Addis Ababa University, School of graduate study.

Government of Pakistan. (1998). National Education Policy 1998-2010. Ministry of Education Islamabad.

Government of Pakistan. Planning Commission (2008). Mid-Term Review of Medium term Development Framework (2005-10). Ministry of Education, Islamabad, Pakistan.

Government of Pakistan. (2009). National Education Policy 2009. Ministry of Education, Islamabad. Pakistan.

Government of Pakistan. (2010). National Plan of Action. Ministry of Education. Islamabad. Pakistan.

Government of Pakistan. (2011). National Plan of Action. Ministry of Education. Islamabad. Pakistan.

Government of Pakistan. (2012). National Plan of Action. Ministry of Education. Islamabad. Pakistan.

Government of Pakistan. (2013). Pakistan Education Statistics 2013-2014. Islamabad: AEPAM.

Iqbal, Z. N. (2006). A comparative study of English medium schools and Urdu medium schools of Sialkot city. (Unpublished thesis of Master of Philosophy (Education)). Department of Teacher Education, Faculty of Education: Allama Iqbal Open University, Islamabad.

Isani, U. A. G., \& Virk, M. L. (2003). Higher education in Pakistan: A historic and futuristic perspective. Islamabad, Pakistan: National Book foundation.

I-SAPS. (2010). Private sector education in Pakistan, Mapping and Musing. Islamabad: Institute of social and policy sciences.

Joshua, A. A. (2012). Improving learning infrastructure and environment for sustainable quality assurance practice in secondary schools in Ondo State, South-West, Nigeria. Retrieved from http://WWW.consortiacademia.org/index.php/ijarse/download/2011/2012

Liaqat, S. (2009). Comparison of quality of teaching between government and private schools. Unpublished Master's Thesis in Education. Division of Education, University of Education, Lahore.

Lue, E. (2005). The role of teachers, schools and communities in quality education: Review of the Literature. Washington, D.C.: Global education center.

Memon, G. R. (2007). Education in Pakistan: The key issues, problems and the new challenges. Journal of Management and Social Sciences, 3(1), 47-55.

Mustaqeem, S. (2008). A comparative study of staff morale of public and private school in Lahore. (Unpublished Thesis of Master in Education). Division of Education, University of Education, Lahore.

NAAC (1995). The quest for quality in higher education. Discussion paper No.1. National assessment and accreditation council of India, Bangalore.

Semaw, G. (2009). Factors affecting EGSECE achievement of students in government and non-government schools of Addis Ababa. (Master's Thesis). School of Graduate Studies of Addis Ababa University, Addis Ababa. Retrieved from http://etd.aau.edu.et/bitstream/ handle/123456789/5232/Getnet\%20Semaw.pdf?sequence=1\&isAllowed=y 
Shami, P. A., \& Hussain, S. K. (2007). Education in Pakistan, Academy of Educational Planning and Management. Islamabad: Ministry of Education, AEPM.

Street, N. W. (2008). Text books and school library. Provision in secondary education in subSaharan Africa. Washington DC: The World Bank.

UNICEF. (2000). Defining quality in education. Working paper series. New York: UNICEF.

Watson, D. (2005). Capacity building for decentralized education services delivery in Pakistan, ECDPM Discussion paper 57G. Maastricht: ECDPM.

\section{Atta Ur Rahman}

Sarhad University of Science and Information Technology, Peshawar

H.NO.E/101-A, Wandhi Ghund wali, Mianwali. 42200, Pakistan attarahman17@yahoo.com

\section{Niaz Muhammad Aajiz}

Islamia College University, Department of Education

Peshawar, Khyber Pakhtunkhwa, Pakistan

niaz@icp.edu.pk 


\section{Procjena kvalitete obrazovanja u privatnim srednjim školama u Khyber Pakhtunkhwi u Pakistanu}

\section{Sažetak}

U ovome istraživanju ispituje se kvaliteta obrazovanja u privatnim srednjim školama u KhyberPakhtunkhwi u Pakistanu. Istraživanje je deskriptivnoga karaktera. Populacija ispitanika sastojala se od ravnatelja, nastavnika i učenika privatnih srednjih škola u Kohatu. Ravnatelji svih 30 privatnih srednjih škola odabrani su za uzorak ispitanika, a tehnikom slučajnoga uzorkovanja odabran je ostatak ispitanika. Izrađena su tri različita upitnika po modelu Likertove skale od 5 stupnjeva. Podatci su interpretirani s pomoću jednostavnih postotaka. Rezultati su pokazali da je većina nastavnika privatnih srednjih škola stručna, no nisu bili zadovoljni svojom plaćom i strukturom zaposlenika u školi. Zaključak je da škole prate kurikul koji propisuje nadležni odbor. U školama postoje laboratoriji za prirodoslovne predmete, no u knjižnicama nedostaju moderna i suvremena literatura.

Ključne riječi: kvalificirani nastavnici; prateći objekti; privatne škole; srednjoškolska razina obrazovanja.

\section{Uvod}

Obrazovanje je sustavan način prikupljanja informacija, stjecanja vještina i razvijanja ambicija pojedinca, koje se zatim prebacuju na sljedeću generaciju, pripremajući i istražujući potencijale. Učenje je društveni alat s pomoću kojega pojedinac usmjerava vlastitu sudbinu i planira svoja očekivanja. Obrazovani pojedinci sposobni su raditi te se tako očekuje od obrazovanja da "proizvede“ učinkovite građane koji će zauzvrat poticati financijski napredak države. Stoga je uloga obrazovanja ključna u procesu stvaranja gospodarstva koje se temelji na učenju, jer obrazovane i talentirane mase preuzimaju važan zadatak - napredak/ uspjeh države. Kako bi se ostvario cilj stvaranja obrazovane i talentirane generacije, iznimno je važno uvelike ulagati u obrazovanje jer će ono pomoći partnerima promijeniti mentalitet i ostvariti maksimalnu stopu pismenosti. I privatni i državni sektor trebaju ispuniti svoje društvene obveze i svakome omogućiti kvalitetno obrazovanje (Pakistan Education Statistics, 2013, 2014).

Kvaliteta obrazovanja općenito jamči društveni razvoj stanovništva. Međutim, kvalitetni rezultati analiziraju se na temelju ulazne kvalitete koja uključuje odlične 
nastavnike, izvrsne obrazovne programe, vrhunsko stanje obrazovnih ustanova, edukacije i administraciju koja jamči jednostavnu primjenu zakona kako bi se ostvarili kvalitetni rezultati. Razvijene nacije odvajaju adekvatna financijska sredstva za organizaciju nastave, a ulaganja u obrazovanje u zemljama u razvoju nedovoljna su. U Pakistanu ulaganja u obrazovanje nisu dostatna (Government of Pakistan, 2009). Stoga su nedostatak financijskih sredstava i popratnih sadržaja doveli do velikoga broja učenika koji odustaju od školovanja (Government of Pakistan, 2011, 2012).

Zbog nedovoljnih sredstava za obrazovanje u proračunu bilo bi nezamislivo da se državni sektor pobrine za obrazovne potrebe brzorastuće populacije Pakistana, sa stopom prirasta od 2,7\%. Tako je normalno očekivati da bi privatni sektor mogao sudjelovati u nastojanjima da se obrazovanje poboljša (Government of Pakistan,2010, 2011). Privatni sektor već duže vrijeme, još od 1947. godine, pruža potporu i dijeli teret s državnim sektorom. Ipak, strategija nacionalizacije (1972. godine) izazvala je goleme frustracije u privatnom sektoru jer mu je ograničila dotok financijskih sredstava. Konačni se rezultat odrazio na upis učenika u obrazovne ustanove koje je financirala država (državne) i one koje nije financirala država (privatne) - omjer je bio 70 : 30 (Isani i Virk, 2003).

Iako je politika nacionalizacije prekinuta 1979. godine, a nacionalizirane škole vraćene su prethodnim vlasnicima, ta vladina politika nemiješanja u privatne škole polarizirala je obrazovni sustav. Vlada Pakistana ne daje financijsku potporu privatnim školama pa one opstaju i ovisne su isključivo o tržišnim čimbenicima. Bez obzira na vladinu politiku nemiješanja, privatni je sektor nakon 1979. uspio proširiti svoje obrazovne usluge čak i na regije, i to u vrlo kratkom vremenu, kako bi se povećala stopa pismenosti stanovništva. Nakon toga je vlada uočila da je brz razvoj privatnog sektora u području obrazovanja u Pakistanu vrlo izgledan, jer su uvjeti u državnim školama bili jako skromni (Wotson, 2005).

\section{Ciljevi istraživanja}

Ovo je istraživanje provedeno sa sljedećim ciljevima:

1. Procijeniti kvalitetu obrazovanja s obzirom na upravljanje kvalitetom, kvalitetu kurikula i kvalitetu popratnih sadržaja, kvalitetu nastavnih metoda i kvalitetu izvannastavnih aktivnosti u privatnim srednjim školama.

2. Analizirati akademske i stručne kvalifikacije nastavnika i njihovu plaću u privatnim srednjim školama.

3. Preporučiti odgovarajuće mjere za poboljšanje obrazovne kvalitete u privatnim srednjim školama.

\section{Pregled literature}

Pojam kvalitete lakše je objasniti nego definirati. Kada uspoređujemo stvari i odaberemo onu bolju, ta koju odaberemo obično ima bolju kvalitetu. Kvaliteta 
se može shvatiti kao nešto što odgovara zadanim standardima (NAAC, 1995). Termin kvaliteta označava stupanj izvrsnosti koji proizvod ili usluga ima. Teško ga je definirati. Pružanje kvalitete podrazumijeva i pristup obrazovanju. Često se koristi kao istoznačnica za izvrsnost. Kvaliteta utječe na to što učenici uče, koliko dobro uče i koje dobrobiti imaju od obrazovanja. Pojam kvalitete uključuje i željene ishode učenja kod učenika i usvajanje vrijednosti i vještina koje im pomažu kako bi igrali pozitivnu ulogu u društvu (Barette, 2006). Kada se uspoređuju privatne i državne škole, smatra se da privatne škole pružaju komercijalizirano obrazovanje koje se koristi u poslovne svrhe, a državne škole pružaju širi tip obrazovanja. Smatra se i da državne škole pružaju kvalitetno obrazovanje djeci (I-SAPS, 2010). Kako je naveo Iqbal (2006), u usporedbi s državnim školama, privatne škole pružaju veći broj nastavnih materijala, njihovi se nastavnici koriste aktivnim metodama poučavanja te organiziraju više izvannastavnih aktivnosti.

Priroda nastavnih materijala koji su dostupni u obrazovnoj instituciji u pozitivnoj je vezi sa zadacima učenja, što rezultira postizanjem zadanih ciljeva (Ayeni i Adelabu, 2012). Školski materijalni uvjeti i nastavni materijali, poput udžbenika i priručnika, smatraju se temeljnim alatima za postizanje akademskog uspjeha učenika. Dostupnost materijala za čitanje i priručnika u školskim knjižarama i knjižnicama sama po sebi ne osigurava kvalitetu škole, osim ako se oni učenicima ne podijele tijekom školske godine (Earthman, 2002).

Glavni i pomoćni nastavni materijali i izvori znanja povezani su s boljim postignućima učenika. Dostupnost nastavnih materijala u zemljama u razvoju ima pouzdano dobar ishod za postignuća učenika. Štoviše, postali su vrlo važan čimbenik u posljednjih nekoliko desetljeća jer je dokazano da su nastavni materijali neophodni i da vode dobrim nastavnim postignućima (Semaw, 2009).

Glavno objašnjenje za slabu kvalitetu obrazovanja bila je priprema nastavnika i opći stav prema njima. U prošlosti je svatko mogao biti nastavnik, i na nižoj i na višoj razini obrazovanja, jer nije bilo sustava provjere sposobnosti i spremnosti kandidata. S ciljem ukidanja takve prakse, postavljeni su kriteriji kojima nastavnici na svakoj razini obrazovanja moraju udovoljavati. Tako svi nastavnici moraju imati odgovarajuće obrazovanje, što je jak temelj za svakoga nastavnika. Najvažniji čimbenici koji utječu na proces učenja i poučavanja su kompetentnost i kvaliteta pojedinog nastavnika.

Girma (2010) tvrdi da postoji jasan dokaz da su nastavnikova kompetentnost i učinkovitost najvažnije odrednice postignuća učenika. Obrazovnu kvalitetu određuje spremnost nastavnika za nastavnički posao. Girma smatra da kvaliteta nastavnika ovisi o razumijevanju i vrsti obrazovanja koje nastavnici imaju. Također ovisi i o ponašanju nastavnika i njegovu odnosu s učenicima. Važne karakteristike kompetentnoga nastavnika su: stručne kvalifikacije, praktični rad u nastavi, iskustvo, sposobnosti i nastavna praksa, rukovanje tehnologijom i sposobnost suradnje s drugim nastavnicima, pojedincima i skrbnicima. Lue (2005) tvrdi da kvalitetan kurikul odgovara očekivanim i provedenim obrazovnim modulima 
u školama, nacionalnim ciljevima obrazovanja i rezultatima koji pokazuju da su ti ciljevi ostvarivi i mjerljivi. Kurikul bi trebao naglasiti dublja i ključna područja učenja, pitanja koja se pojavljuju u kontekstu učenja i kritičko mišljenje te inzistirati na razvoju sposobnosti i prikupljanju informacija. UNICEF (2000) objašnjava da interesi zajednice mogu biti dodatna vrijednost kvalitete nastavnih sadržaja i da na nju mogu utjecati. U svakom slučaju, u svim državama sadržaj kvalitete trebao bi pokrivati sljedeća važna područja: stručnost, numeričku pismenost, životne vještine i mirovne studije, kao i znanost i društvene studije.

Bedi i Garg (2000) su, na temelju podataka iz Indonezije, potvrdili da učenici koji su primljeni u privatne srednje škole postižu bolje rezultate u usporedbi s onima koji su pohađali državne škole. Analizirali su razlike u rezultatima učenika iz državnih i privatnih škola. Pokazalo se da učenici koji su završili privatne škole poslije u životu dobivaju veću plaću od svojih vršnjaka koji su završili državne škole.

Joshua (2012) navodi da u razvijenim školama roditelji/skrbnici posjećuju škole kako bi utvrdili njihovu dostupnost i popratne sadržaje prije nego što odluče upisati svoju djecu u jednu od njih. I u zemljama u razvoju ministarstva obrazovanja smatraju da popratni sadržaji u školama imaju utjecaj na interes i kvalitetu. U konačnici, školski popratni sadržaji su alati s pomoću kojih se privlače novi učenici, pogotovo djevojke. Oni imaju odlučujuću ulogu i mogu impresionirati učenike. Škola s popratnim sadržajima jamči da će učenici učiti u standardnom okruženju. Osnovni standardni sadržaji koje bi škola trebala imati su:

(i) Odvojeni sanitarni čvorovi za dječake i djevojčice.

(ii) Odgovarajuće slavine gdje se djeca mogu oprati i piti vodu.

(iii) Savjetodavna služba za učenike kojima je potrebno savjetovanje u vezi s obrazovanjem.

(iv) Odgovarajuća knjižnica i laboratoriji koji odgovaraju razini obrazovanja i igralište.

On nadalje dodaje da način na koji je škola ustrojena, namještaj u njoj, privlačne učionice i dostupnost nastavnih materijala potiču nastavnike na bolji rad, a učenike na bolja akademska postignuća. Street (2008) navodi da bez obzira na to utječe li školski laboratorij na studentska akademska postignuća ili ne utječe, njegova se važnost ne smije umanjiti. On smatra da školski laboratorij kao praktikum pozitivno utječe na učenička postignuća. Broj učenika u učionici u kojoj se provode istraživanja i u laboratoriju povezuju se s postignućima. Osim toga, dokazano je da školski laboratorij pozitivno utječe na akademska postignuća učenika. Getahun (2002) navodi da školske knjižnice postaju poveznicom između predmeta koje učenici uče i da im pomažu kako bi mogli primijeniti znanstvene i aritmetičke ideje u drugim disciplinama. Knjižnice su mjesta gdje se mogu razvijati obrazovni programi u području prirodnih znanosti, gdje elektroničke baze podataka sadrže najnovije podatke, gdje se pozivaju predavači i gdje učenici mogu prezentirati svoje 
projekte. Izvješće Svjetske banke obuhvatilo je 18 studija o utjecaju veličine knjižnice i aktivnostima koje se u njoj odvijaju na učenička postignuća. U 15 slučajeva utvrđen je pozitivan utjecaj, što potvrđuje da školske knjižnice imaju važnu ulogu u učeničkim postignućima. Učenici koji rade u dobro opremljenim knjižnicama postižu dobre rezultate, za razliku od onih koji rade i uče u loše opremljenim knjižnicama.

Štoviše, Farida i Madiha (2000) u svojem su radu došli do zaključka da su ravnatelji u privatnim školama pod većim pritiskom zbog izvannastavnih aktivnosti jer ih smatraju obveznom komponentom nastave.

U izvješću ASER Pakistan (2010) navodi se da državne škole imaju veći broj učionica, bolju pitku vodu, sanitarne čvorove i vanjske zidove koji jamče sigurnost. Što se tiče učenja i obrazovnih postignuća u školama u Punjabiju (LEAPS), standardi učenja u privatnim školama bolji su od onih u državnim školama iako se bolji uvjeti i plaća nude nastavnicima u državnom sektoru. Svejedno, pakistanska vlada iskreno je zabrinuta i propisuje kontrolu rada u privatnim obrazovnim ustanovama s obzirom na sposobnosti nastavnika, obrazovne programe, prateće objekte, jer biti ovisan o privatnim organizacijama predstavlja rizik. Trend praktičnih i znanstvenih eksperimenata u privatnim srednjim školama polako jenjava, što će rezultirati lošim posljedicama za obrazovanje. Stoga postoji potreba ponovnog uvođenja privatnojavnog partnerstva, jer je glavni cilj privatnoga sektora sklonost ostvarivanju profita. Postoji dodatna bojazan da privatni sektor smanjuje plaće i prava radnika. U privatnom sektoru zaposlenici imaju manje izgleda za napredovanje i povlastice, jer bi to zahtijevalo velike promjene, pa se odanost $\mathrm{i}$ iskrenost nastavnika može dovesti u pitanje (Government of Pakistan, 2008). Drugi razlog zašto je regulacija potrebna odnosi se na stručnost i kvalifikacije nastavnika koji rade u privatnim školama. Većina privatnih škola zapošljava niskokvalificirane i nedovoljno obrazovane nastavnike. Nekoliko se istraživanja bavilo tim aspektom kvalitete. Uistinu, čak su neke privatne škole u udaljenim regijama zaposlile lokalne stanovnice kao nastavnice, iako one nikada nisu prošle ni kroz kakav oblik edukacije izvan svojega mjesta stanovanja (Andrabi i sur., 2002). Mustaqeem (2008) pretpostavlja da nastavnici u privatnim školama imaju veću odlučnost od onih u državnim školama. Osim toga, Liaqat (2009) je došao do spoznaje da je kvaliteta obrazovanja u privatnim školama bolja, u usporedbi s državnim školama, i da učenici postižu bolje rezultate od učenika u državnim školama.

\section{Metodologija istraživanja}

Istraživanje je deskriptivnog karaktera. Populacija ispitanika sastojala se od ravnatelja, nastavnika i učenika privatnih srednjih škola u Kohatu. Svi ravnatelji $(\mathrm{N}=30)$ privatnih srednjih škola odabrani su u uzorak ispitanika, a primjenom tehnike slučajnog uzorkovanja odabralo se 300 učenika desetoga razreda i 150 nastavnika, i to po 10 učenika i po 5 nastavnika iz svake škole. Osnovne informacije prikupljene su od ravnatelja, nastavnika i učenika privatnih srednjih škola u Kohatu. 
Postupak istraživanja prilagođen je kako bi se dobila mišljenja ispitanika s pomoću triju različitih upitnika - za ravnatelje, učenike i nastavnike. Cronbachovom alfom izražena je unutarnja konzistencija tvrdnji u upitnicima. Alfa vrijednost za svako pitanje bila je viša od 0,89 .

Tvrdnje u upitnicima sastavljene su s pomoću Likertove skale od 5 stupnjeva. Izračunati su postotci kako bi se ispitali podatci. Rezultati su dobiveni na temelju izračuna.

\section{Analiza podataka i rezultati}

$\mathrm{U}$ ovome dijelu rada prikazuju se istraživanje i interpretacija informacija prikupljenih putem upitnika za ispitanike, kao i podatci o privatnim srednjim školama (ravnatelji, nastavnici i učenici iz Kohata).

Tablica 1

Iz Tablice 1 vidljivo je da u privatnim srednjim školama u Kohatu više od polovine zaposlenika ima magisterij, a da su $36 \%$ zaposlenika sveučilišni prvostupnici.

Tablica 2

Tablica 2 pokazuje da je gotovo jedna četvrtina nastavnika neobrazovana i da oko $10 \%$ njih nema odgovarajuću izobrazbu za srednjoškolske nastavnike. 32\% nastavnika ima magisterij, a 33\% njih ima stupanj sveučilišnog prvostupnika.

Tablica 3 i 4

Tablice 3 i 4 pokazuju da su nastavnici nezadovoljni plaćom. U privatnim srednjim školama ne postoje poticaji, odgovarajuća kadrovska struktura u školi ni razumna plaća za nastavnike.

\section{Tablica 5}

Tablica 5 pokazuje da su obrazovni moduli u privatnim školama dinamični i ujednačeni na srednjoškolskom stupnju, što odgovara potrebama društva. Te škole prate obrazovne module Odbora za udžbenike u Peshawaru, Khyber Pakhtunkhwa, a koje su propisali Odbori za srednje i srednjoškolsko obrazovanje.

\section{Tablica 6}

Tablica 6 pokazuje da u privatnim srednjim školama postoji dovoljan broj sanitarnih čvorova, pitka voda, namještaj, učionice i igrališta; ipak ne postoji dovoljan broj suvremene literature u knjižnicama tih škola.

\section{Tablica 7}

Tablica 7 pokazuje da su nastavnici u privatnim srednjim školama kvalificirani i da se koriste modernim nastavnim metodama. Nastavnici stvaraju demokratsko okruženje za učenje i redovito od učenika traže povratne informacije. 


\section{Tablica 8}

Tablica 8 pokazuje da se u većini privatnih škola koristi engleski jezik u provedbi nastave te da imaju bolji omjer nastavnika i učenika. Upravljanje razredom i disciplina u tim se školama učinkovito provode.

\section{Rasprava}

Glavni je razlog ovoga istraživanja bio ispitati održivost sudjelovanja privatnoga sektora u provedbi kvalitetne nastave u srednjim školama u Kohatu. Srednjoškolska razina obrazovanja ima ključno mjesto u obrazovnom okviru jer ona priprema za gospodarstvo osnovnu radnu snagu, a ujedno je i temelj za daljnje obrazovanje. Privatni sektor bio je skloniji kvantitativnom aspektu i fokusirao se na kvalitetu u srednjoškolskom obrazovanju.

Vlast ima središnju ulogu u organizaciji jer je odgovorna za funkcioniranje cijelog školskog sustava. Ovo je istraživanje pokazalo da jedna četvrtina srednjoškolskih nastavnika nije odgovarajuće obrazovana i da samo 10\% nastavnika nema akademske kvalifikacije za izvođenje nastave u srednjoj školi, a da većina nastavnika ima potrebne akademske kvalifikacije. Andrabi i suradnici (2002) također podržavaju rezultat ovoga istraživanja koji pokazuje da velika većina privatnih škola zapošljava nastavnike koji nemaju odgovarajuće profesionalne kvalifikacije. Isto tvrdi i Memon (2007), koji je došao do spoznaje da veći dio privatnih škola zapošljava niskokvalificirane nastavnike koji nemaju potrebna znanja o psihologiji učenika i nastavnim strategijama. Takve organizacije odbacuju nastavnike koji su sveučilišni prvostupnici ili imaju magisterij, a umjesto njih zapošljavaju osobe koje imaju bolje znanje engleskoga jezika. Štoviše, u privatnim školama ne postoji sigurnost zaposlenja, kadrovska struktura ni motivacija nastavnika.

Nastavnici nisu zadovoljni plaćama. Tako se u njima stvara osjećaj depriviranosti i na privatne škole gledaju kao na privremeni posao. Zbog osjećaja nesigurnosti daju otkaze, a to negativno utječe na psihologiju učenika. Memon (2007) se također slaže $\mathrm{s}$ tvrdnjom da $\mathrm{u}$ privatnim školama nedostaje mehanizam potpore nastavnicima. Nastavnici u privatnom sektoru nemaju puno interesa zbog slabe kadrovske strukture i nesigurnosti radnog mjesta.

Privatne škole imaju zadovoljavajući broj sanitarnih čvorova, pitku vodu, namještaj i igralište, no nedostaju im suvremene knjige u knjižnicama. Učenici također smatraju da privatne srednje škole organiziraju izvannastavne aktivnosti zato što imaju veći prostor, a svoje učenike potiču na to da se uključe u različite aktivnosti, poput školskih sportova. Iqbal (2006) se također slaže s rezultatom ovoga istraživanja da privatne engleske škole imaju manje razrede i organiziraju izvannastavne aktivnosti u velikom prostoru, za razliku od državnih škola u Urduu.

Kurikul je plan pažljivo osmišljenih aktivnosti koje su odabrane kako bi se ostvarili željeni ciljevi. Ako on nije dobro definiran, učenici i nastavnici mogu uzalud odrađivati razne aktivnosti. Suprotno mišljenjima da privatne škole nude 
strane kurikule, ovo je istraživanje pokazalo da postoji usklađenost u kurikulima i obrazovnim programima u državnim i u privatnim srednjim školama. $S$ druge strane, većina privatnih škola registrirana je u Odboru za srednje i srednjoškolsko obrazovanje u provinciji i moraju pratiti kurikul koji propisuje nadležni odbor.

\section{Zaključci}

1. Nastavnici i ravnatelji imaju negativno mišljenje o privatnim srednjim školama jer one ne pružaju sigurnost zaposlenja, nagrade, nemaju kadrovsku strukturu ni odgovarajuću plaću za nastavnike. Zato nastavnici nisu zadovoljni svojim plaćama.

2. Učenici i ravnatelji imaju pozitivne stavove o nastavnim metodama koje nastavnici primjenjuju. Mišljenja su da su nastavnici stručnjaci, svaki u svojem području.

3. Učenici su se složili s tvrdnjama o školskim pratećim sadržajima - pitkoj vodi, odgovarajućem broju sanitarnih čvorova i namještaju u privatnim školama. Ipak, suprotno tome, naveli su negativne stavove zbog nedostatka prostora u kojima bi mogli provoditi znanstvena istraživanja i zbog neopremljenosti knjižnica.

4. U ovom su se istraživanju dobila mišljenja učenika i nastavnika da su izvannastavne aktivnosti organizirane $u$ privatnim školama te se učenici $u$ njih uključuju. Većina nastavnika imala je vrlo pozitivna mišljenja o interesu učenika za izvannastavne aktivnosti.

5. Većina učenika imala je izrazito pozitivne stavove o standardu privatnih srednjih škola s obzirom na nastavne metode, razrede i omjer nastavnika i učenika.

\section{Preporuke}

1. Nastavnici u privatnim srednjim školama moraju imati siguran posao. Također bi se trebala napraviti kadrovska struktura.

2. Plaće nastavnika u privatnim srednjim školama trebale bi se izjednačiti s plaćama nastavnika koji rade u državnim školama.

3. Privatne srednje škole trebale bi se opremiti dostatnom suvremenom literaturom.

4. Nesigurnost nastavnika u privatnim srednjim školama trebala bi se ukloniti tako da ih se motivira i ponudi financijska stimulacija.

5. Trebale bi se organizirati različite edukacije kako bi se nastavnici koji nisu kvalificirani mogli izjednačiti s onima koji jesu. 